\title{
NUCLEAR DNA AMOUNTS IN POPULATIONS OF PICEA AND PINUS SPECIES
}

\author{
S. B. TEOH and $H$. REES \\ Department of Agricultural Botany, University College of Wales, Penglais, Aberystwyth
}

Received 26.ix.75

\section{SUMMARY}

There are numerous reports of a very wide range of variation in nuclear DNA amounts among populations within species of the Pinaceae, including Picea glauca, the White Spruce. Our survey of 26 provenances, covering almost the entire range of White Spruce in North America showed, in contrast, no significant variation in nuclear DNA amount within the species except for minor fluctuations due to $\mathrm{B}$ chromosomes. The DNA estimates, throughout, fall within the range of 37.4 to $40.4 \times 10^{-12} \mathrm{~g}$. The areas of the $2 C$ nuclei measured at $G 1$ from 12 provenances were also highly uniform. In addition, there was no significant variation in the chromosome volume between and within provenances. Both facts reinforce the conclusion that nuclear DNA amounts within the species are constant.

There are no detectable differences in the nuclear DNA content between $P$ icea glauca and $P$. engelmannii. In Pinus contorta as in $P$. glauca, nuclear areas and DNA amounts do not vary significantly between or within provenances and the mean DNA value of $2 C$ nuclei is $40 \cdot 34 \times 10^{-12} \mathrm{~g}$.

White Spruce in North America alone ranges over 3000 miles of longitude and some 1000 miles of latitude. The constancy of the nuclear DNA amounts among provenances of White Spruce and of the other species growing in widely differing environments is both surprising and impressive. It provides further testimony to the pronounced inertia to quantitative DNA change within species.

\section{INTRODUCTION}

THERE is a wide range of variation in nuclear DNA amount among both prokaryote and eukaryote species (see Sparrow et al., 1972). In the flowering plants, for example, the DNA amount varies more than a 100 -fold between diploid species alone (Rees, 1972) and even within one family, the Ranunculaceae, the amount varies by a factor of 40 (Rothfels et al., 1966). While the wide-ranging variation in nuclear DNA among species of flowering plants and of other groups of plants and animals is well established, it has been generally assumed that, aside from numerical chromosome change, the DNA amount within species is constant (Boivin et al., 1948; Mirsky and Ris, 1949; Swift, 1950a, 1950b). More recently, however, two kinds of evidence indicate that DNA constancy is not invariable within a species. Firstly, there is evidence that the number of genes coding for ribosomal RNA at the bobbed locus in Drosophila varies between individuals even within the one population (Ritossa and Spiegelman, 1965). This implies, of course, a variation in DNA amount. There is variation also in the number of ribosomal RNA genes between varieties of wheat and of rye (Flavell and Smith, 1974). These molecular changes affect only a small proportion of the total DNA and are detectable only by special techniques of much refinement. The second kind of evidence is more startling. It comes from surveys of 
Gymnosperm species in North America. As shown in table 1, differences of up to 60 per cent in nuclear DNA have been reported in Picea glauca, the White Spruce, and up to 126 per cent in Pseudotsuga menziesii, the Douglas Fir. The intraspecific variation reported is mainly between different populations or provenances but variation between plants within provenances has also been reported in the Douglas Fir by El-Lakany and Sziklai (1971).

\section{TABLE 1}

Evidence for interspecific variation in nuclear DNA content within Gymnosperm species

\begin{tabular}{|c|c|c|c|}
\hline Species & $\begin{array}{l}\text { Type of } \\
\text { variation }\end{array}$ & $\begin{array}{l}\text { Factor of } \\
\text { variation }\end{array}$ & Reference \\
\hline Picea glauca & $\begin{array}{l}\text { Interprovenance } \\
\text { Interprovenance }\end{array}$ & $\overline{1 \cdot 6}$ & $\begin{array}{l}\text { Mergen and Thielges (1967) } \\
\text { Miksche (1968) }\end{array}$ \\
\hline Pinus banksiana & $\begin{array}{l}\text { Interprovenance } \\
\text { Interprovenance }\end{array}$ & $\overline{1 \cdot 5}$ & $\begin{array}{l}\text { Mergen and Thielges (1967) } \\
\text { Miksche (1968) }\end{array}$ \\
\hline Picea sitchensis & Interprovenance & $\begin{array}{l}1.92,1 \cdot 36 \\
1 \cdot 72\end{array}$ & Mergen and Thielges (1967) \\
\hline $\begin{array}{l}\text { Pinus sylvestris } \\
\text { Pinus resinosa } \\
\text { Pseudotsuga menziesii }\end{array}$ & $\begin{array}{l}\text { Interprovenance } \\
\text { Interprovenance } \\
\text { Inter- and } \\
\text { Intraprovenance }\end{array}$ & $\begin{array}{c}\overline{2 \cdot 2} \\
2 \cdot 0,2 \cdot 26\end{array}$ & $\begin{array}{l}\text { Mergen and Thielges (1967) } \\
\text { Dhir and Miksche (1974) } \\
\text { E1-Lakany and Sziklai (1971) }\end{array}$ \\
\hline
\end{tabular}

The chief aim of the present work was to inquire in detail into the distribution of quantitative nuclear DNA variation in Picea glauca and, as far as possible, to ascertain the consequences of such variation. Results are also presented on nuclear DNA variation among two other species in the Pinaceae.

\section{Materials AND METHODS}

(i) Materials

Seeds of Picea glauca (White Spruce) from a wide range of provenances were obtained from the sources listed in table 2. Details are given of the latitude, longitude and, where possible, of the altitude of the provenances. Most of the provenances were derived from general collections i.e. seeds pooled from several trees. The investigation also dealt with some seeds from single trees, as indicated in the table.

Seedlings of Picea engelmannii (Engelmann Spruce) and of Pinus contorta Doug. were also investigated (see table 2).

\section{(ii) Chromosome measurements}

Roots were pretreated with 0.5 per cent colchicine for $4 \frac{1}{2}$ hours. They were then fixed in a 3:1 alcohol-acetic acid after which hydrolysis was carried out in $5 \mathrm{~N}-\mathrm{HCl}$ for 1 hour at room temperature $\left(20^{\circ} \mathrm{C}\right)$, stained in Feulgen solution and squashed in acetocarmine.

Measurements were made in $c$-metaphases under the oil immersion lens using a Vickers Instrument eyepiece attachment with a moving scale that gave a high degree of accuracy. The chromosomes in each cell were measured individually for length and five chromosomes in each cell taken at random to obtain the mean chromatid width. The volume was then calculated on the assumption that each chromosome is made up of two parallel chromatids, each being cylindrical in form. 
TAble 2

List of seed sources

1. Picea glauca

Provenance code

57

81

82

63

65

391

467

403

395

$477-2$

$481-2$

$94 \mathrm{~J} 15$

104A6

9313

GK06

71442

72374

71045

70079

70118

70112

70076

70075

70114

70074

70113

72114

72127

Lat. ${ }^{\circ} \mathrm{N}$
$49^{\circ} 10^{\prime}$
$50^{\circ} 08^{\prime}$
$51^{\circ} 08^{\prime}$
$54^{\circ} 56^{\prime}$
$55^{\circ} 28^{\prime}$
$45^{\circ} 58^{\prime}$
$46^{\circ} 17^{\prime}$
$47^{\circ} 37^{\prime}$
$49^{\circ} 15^{\prime}$
$48^{\circ} 07^{\prime}$
$48^{\circ} 50^{\prime}$
$58^{\circ} 50^{\prime}$
$56^{\circ} 20^{\prime}$
$54^{\circ} 06^{\prime}$
$64^{\circ} 54^{\prime}$
$51^{\circ} 37^{\prime}$
$61^{\circ} 21^{\prime}$
$49^{\circ} 01^{\prime}$
$48^{\circ} 53^{\prime}$
$53^{\circ} 20^{\prime}$
$45^{\circ} 42^{\prime}$
$48^{\circ} 15^{\prime}$
$46^{\circ} 00^{\prime}$
$46^{\circ} 02^{\prime}$
$49^{\circ} 05^{\prime}$
$47^{\circ} 15^{\prime}$
$44^{\circ} 55^{\prime}$
$44^{\circ} 45^{\prime}$

Long. ${ }^{\circ} \mathrm{W}$

$120^{\circ} 35^{\prime}$

$115^{\circ} 26^{\prime}$

$117^{\circ} 05^{\prime}$

$127^{\circ} 00^{\prime}$

$127^{\circ} 50^{\prime}$

$71^{\circ} 21^{\prime}$

$75^{\circ} 23^{\prime}$

$74^{\circ} 15^{\prime}$

$72^{\circ} 50^{\prime}$

$66^{\circ} 07^{\prime}$

$72^{\circ} 50^{\prime}$

$122^{\circ} 48^{\prime}$

$129^{\circ} 15^{\prime}$

$121^{\circ} 23^{\prime}$

$146^{\circ} 26^{\prime}$

$119^{\circ} 50^{\prime}$

$139^{\circ} 00^{\prime}$

$57^{\circ} 37^{\prime}$

$58^{\circ} 36^{\prime}$

$60^{\circ} 25^{\prime}$

$61^{\circ} 56^{\prime}$

$65^{\circ} 27^{\prime}$

$66^{\circ} 21^{\prime}$

$77^{\circ} 17^{\prime}$

$81^{\circ} 15^{\prime}$

$83^{\circ} 35^{\prime}$

$78^{\circ} 05^{\prime}$

$78^{\circ} 08^{\prime}$

2. Picea engelmannii

$\begin{array}{ll}\text { N110 } & 49^{\circ} 30^{\prime} \\ \text { N86 } & 49^{\circ} 42^{\prime} \\ \text { N27 } & 50^{\circ} 12^{\prime}\end{array}$

$115^{\circ} 37^{\prime}$

$115^{\circ} 38^{\prime}$

$115^{\circ} 03^{\prime}$

$\begin{array}{ll}5300 & \text { STC } \\ 5500 & \text { STC } \\ 4000 & \text { STC }\end{array}$

Alt.

(ft.) Coll

4000 GC

4600 GG

4300 GC

2000 GC

1500 GC

$1150 \quad \mathrm{GC}$

700 GC

1500 GC

1100 GC

200 STC

800 STC

1750 GC

1500 GC

2600 GC

- GC

$1400 \mathrm{GC}$

- STC

150 GC

150 GC

- GC

200 GC

1200 GC

250 GC

500 GC

950 GC

750 GC

- STC

- STC

M. Henrich (Koksilah Reforestation Complex, B.C.)

G. Kiss (B.C. Forest Service)

B. S. P. Wang (Petawawa Forest

Exp. Station, Ontario)

3. Pinus contorta

\begin{tabular}{|c|c|c|c|c|c|}
\hline SK65(7114) 13 & $57^{\circ} 00^{\prime}$ & $127^{\circ} 00^{\prime}$ & 2000 & 一 & G. M. Buszewicz (Forestry \\
\hline SK72(7114)1 & $54^{\circ} 52^{\prime}$ & $128^{\circ} 49^{\prime}$ & 500 & 一 & Commission, Surrey, England) \\
\hline CI65(7113)1 & $54^{\circ} 02^{\prime}$ & $124^{\circ} 00^{\prime}$ & 2500 & - & \\
\hline CI65(7113) 3 & $52^{\circ} 00^{\prime}$ & $125^{\circ} 00^{\prime}$ & 4250 & - & \\
\hline SI65(7118)1 & $50^{\circ} 50^{\prime}$ & $119^{\circ} 20^{\prime}$ & 3500 & - & \\
\hline SC65(795) & $42^{\circ} 30^{\prime}$ & $123^{\circ} 00^{\prime}$ & - & - & \\
\hline $63(7957)$ & $43^{\circ} 25^{\prime}$ & $121^{\circ} 35^{\prime}$ & - & - & \\
\hline SK72(4265) 1 & $54^{\circ} 45^{\prime}$ & $127^{\circ} 06^{\prime}$ & — & 一 & \\
\hline SK72(4265) 2 & $54^{\circ} 30^{\prime}$ & $128^{\circ} 36^{\prime}$ & - & - & \\
\hline
\end{tabular}

(iii) Estimation of nuclear DNA amount and area

The nuclear DNA amount was estimated by Feulgen photometry using a Vickers M85 Microdensitometer. The instrument also gives, simultaneously, estimates of the nuclear area. Preparations of root meristems were made initially by fixing in 3:1 alcohol-acetic acid or in Carnoy's solution followed by hot hydrolysis at $60^{\circ} \mathrm{G}$, a method similar to Miksche's 
(1971). However, this method was abandoned due to poor nuclear stainability, to such an extent that DNA estimates for White Spruce were often lower than for Allium cepa used as a control. Above all, the method gave highly inconsistent readings both within and between slides.

The method adopted eventually, and one which gave consistent results, was as follows:

(a) Fixation. Root-tips were fixed in 4 per cent formaldehyde in neutral phosphate buffer for 2 hours, followed by thorough washing in distilled water for 24 hours. The roots were then washed in distilled water for 30 minutes. This procedure was developed and recommended to us by D. P. Fox of Aberdeen, to whom we are grateful.

(b) Hydrolysis. Roots were hydrolysed in $5 \mathrm{~N}-\mathrm{HCl}$ at room temperature $\left(20^{\circ} \mathrm{C}\right)$. Recent comparative studies have shown cold hydrolysis to be more reliable than the more conventional technique of hydrolysing in $1 \mathrm{~N}-\mathrm{HCl}$ at $60^{\circ} \mathrm{C}$ (Decosse and Aiello, 1966; Deitch, Wagner and Richart, 1968; Fox, 1969a, 1969b; Edwards, Endrizzi and Stein, 1974).

For White Spruce the optimum duration of hydrolysis ( 1 hour) was established experimentally. The results of the experiment are summarised in fig. 1. Cold hydrolysis (in contrast to hot) leads to a long plateau of maximum staining following hydrolysis for 40 to 70 minutes. Small fluctuations in hydrolysis time around 60 minutes are, therefore, permissible and this in itself is important when 60 or more roots are handled simultaneously.

(c) Staining. After hydrolysis the roots were washed for 1 minute in distilled water, dried briefly on absorbent paper and then stained in Feulgen solution adjusted to $p \mathrm{H} 2 \cdot 2$ with $1 \mathrm{~N}-\mathrm{NaOH}$.

The optimum time at which the maximum binding of stain is achieved was determined by varying the time of immersion of roots in Feulgen stain. The results are presented in fig. 1. Maximum staining intensity is achieved after 15 minutes and continues for up to 2 hours. On the basis of the results in fig. 1, l hour was taken as the optimum. After staining, roots were washed for 30 minutes in three changes of $\mathrm{SO}_{2}$ water to bleach any stain out of the cytoplasm. The roots were transferred to distilled water, and subsequently squashed under a cover slip in glycerol on slides of thickness 1.2$1.5 \mathrm{~mm}$ (Chance Propper Ltd.).

(d) Measurement of stain. The amount of Feulgen stain per nucleus, in arbitrary units, was measured at $570 \mathrm{~m} \mu$ on the M85 Vickers Microdensitometer. All measurements, unless stated otherwise, were made on $2 C$ nuclei at late telophase-a stage easily recognised.

(e) The control. Roots of Allium cepa, used as a control, were in all cases fixed, hydrolysed and stained together with the roots of Picea glauca. This was essential because estimates of DNA values can fluctuate between experiments due to many factors, e.g. different preparations of fixative, different preparations of stain, fluctuation of $p \mathrm{H}$ of stain, temperature variation, mechanical set-up of microdensitometer, etc. By using the control the results from different experiments could then be weighted using the control values. DNA estimates within each experiment were made over as short a period as possible, not more than 5 days. Even so, there was evidence of fading in the slides (replicates) scored last. By use of a control with each replicate, however, it was possible to correct for such fading. The control, therefore, was utilised for correcting " error" in estimates both between and within experiments. 


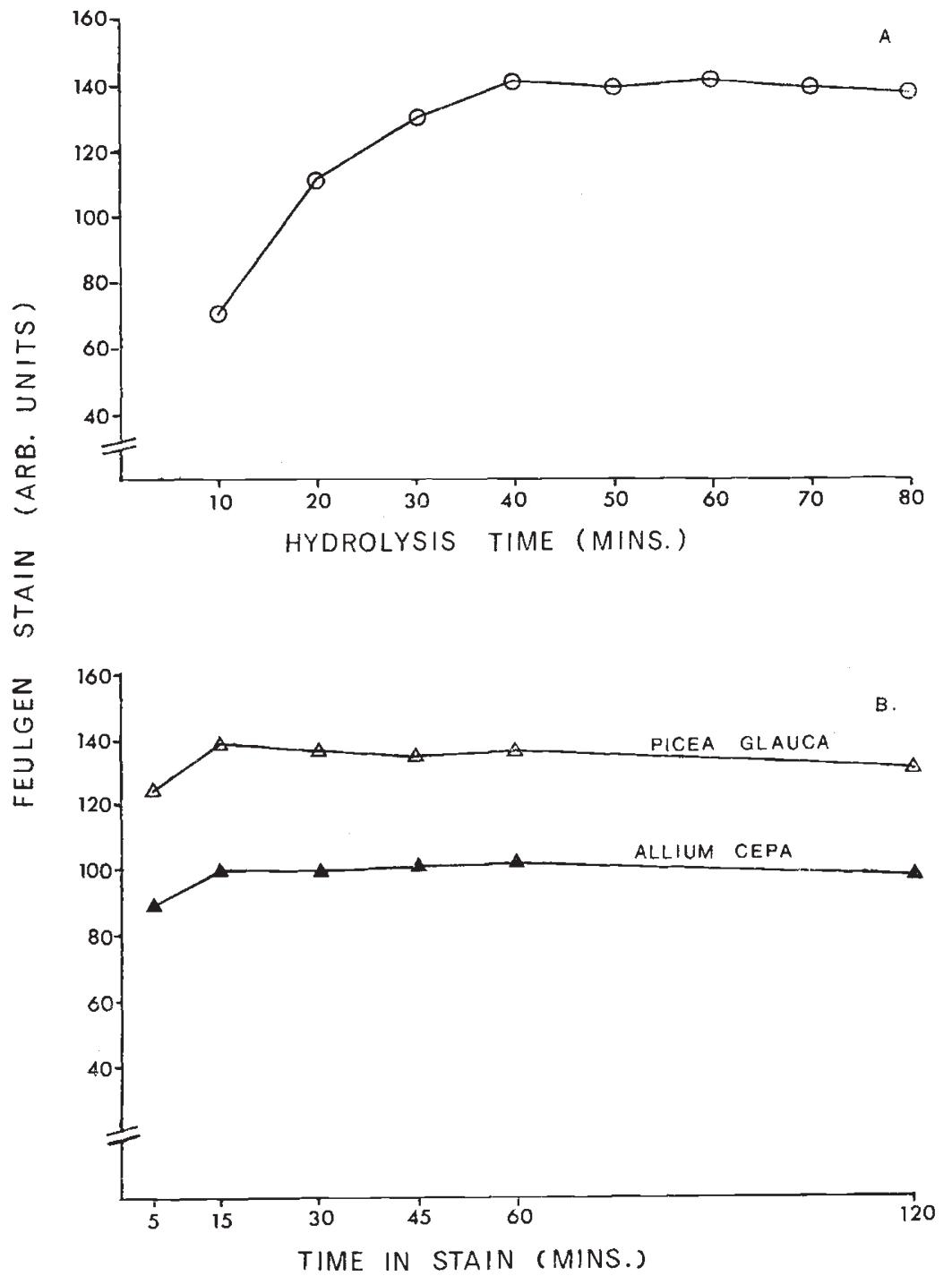

Frg. 1.-The relationship between the intensity of Feulgen staining of $2 C$ nuclei in (a) Picea glauca with varying periods of hydrolysis in $5 \mathrm{~N} \mathrm{HCl}$ at $20^{\circ} \mathrm{C}$ and $(b)$ in Picea glauca and Allium cepa after varying periods of immersion in Feulgen stain. The parallel changes in staining intensity shown by Picea glauca and Allium cepa indicates that $A$. cepa is a suitable control in the sense that it responds in the same way as $P$. glauca to variations in staining procedure.

\section{Results}

(i) Picea glauca

(a) B chromosomes

A detailed account of the B chromosomes in White Spruce will be published in a subsequent paper; it is sufficient to mention in passing that B chromosomes are of widespread occurrence in this spruce species and 
could be easily detected at interphase as well as metaphase. Since B chromosomes contribute to the DNA content of the nuclei, it was clearly important to separate the effects of B's upon the nuclear DNA variation between populations from any effects due to variation in chromosomes of the normal complement (A chromosomes) such as are postulated by Miksche (1968).

Apart from B chromosomes, all the plants examined were diploids with 24 chromosomes (fig. 2a).

TABLE 3

Unweighted DNA amounts in 2C nuclei of Picea glauca from 26 provenances

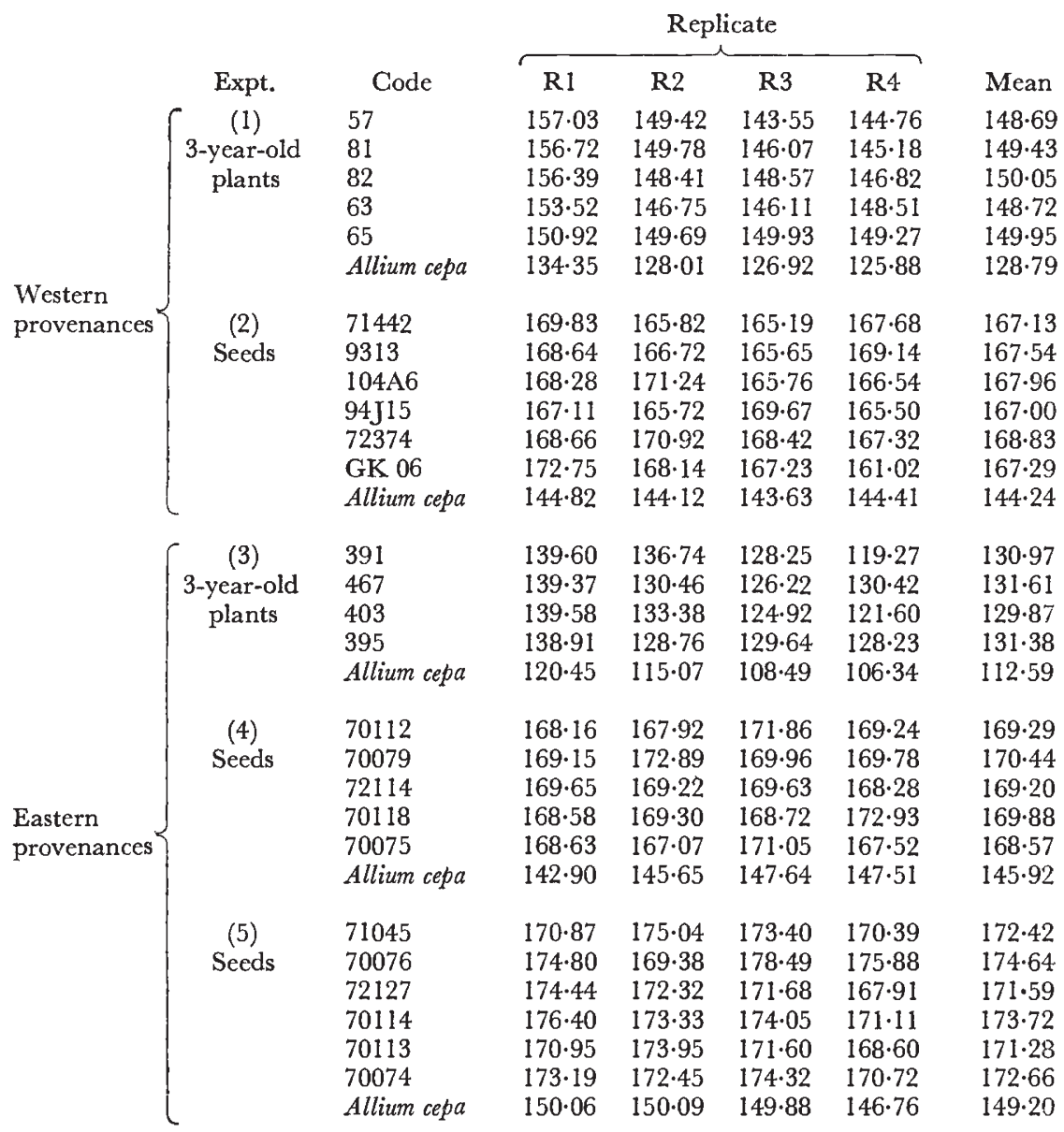

(b) Variation in nuclear $D \mathcal{N} A$ content

The nuclear DNA content was estimated in root-tips either of germinating seeds or of 3-year-old plants. The seeds and plants were obtained from 26 provenances and the estimates were made in five separate experiments from four seeds or plants (replicates) in each provenance. The value for each replicate is the mean of $152 \mathrm{C}$ nuclei chosen at random from each root-tip. Altogether a total of 1560 nuclei was measured. The provenances were arbitrarily divided into Eastern and Western at the 95th meridian (see 

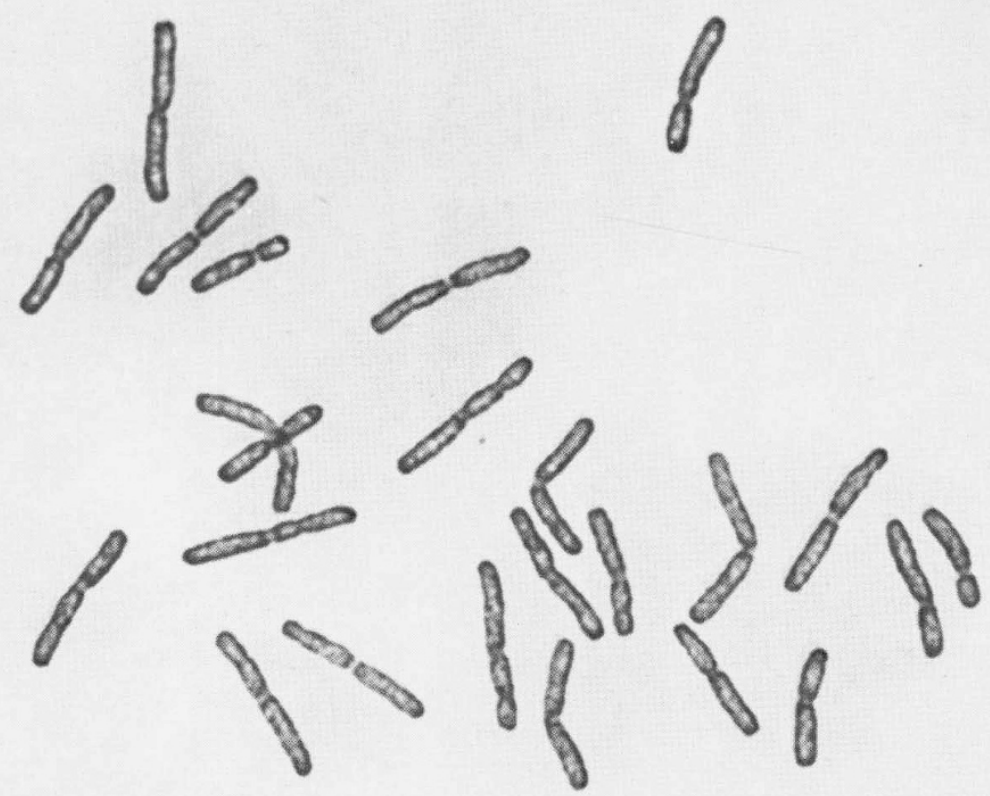

a
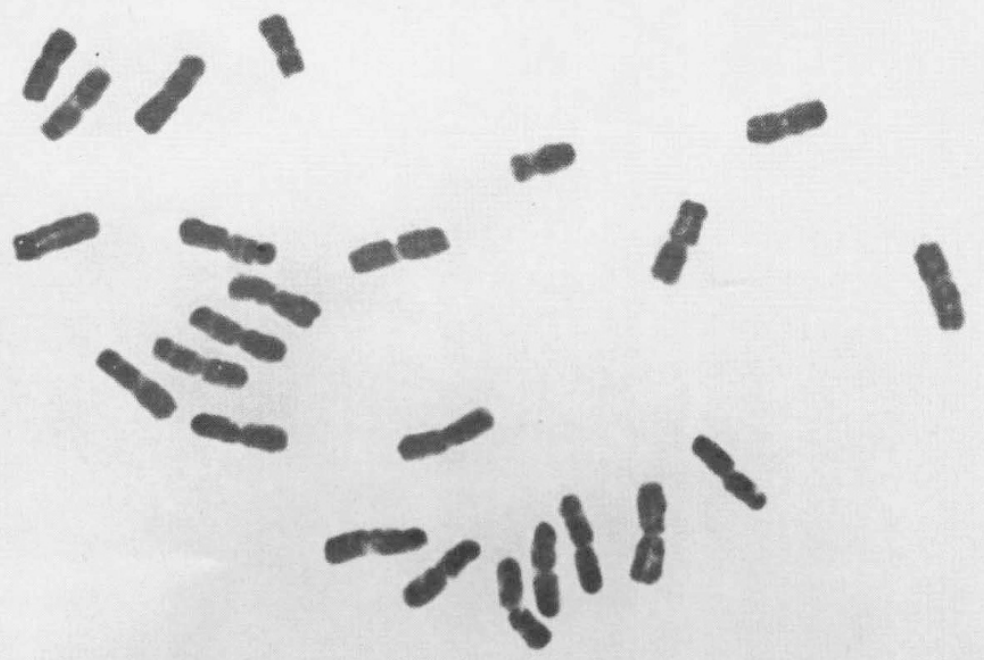

b

Plate I

Frg. 2.-Diploid chromosome complements from the root-tips of two Gymnosperm species. (a) Picea glauca, $2 n=24$ and (b) Pinus contorta, $2 n=24$. 
Miksche, 1968). It needs to be emphasised that only plants without B's were used in the DNA estimation. There is no question of confounding DNA variation due to B's with that due to variation in the normal complement.

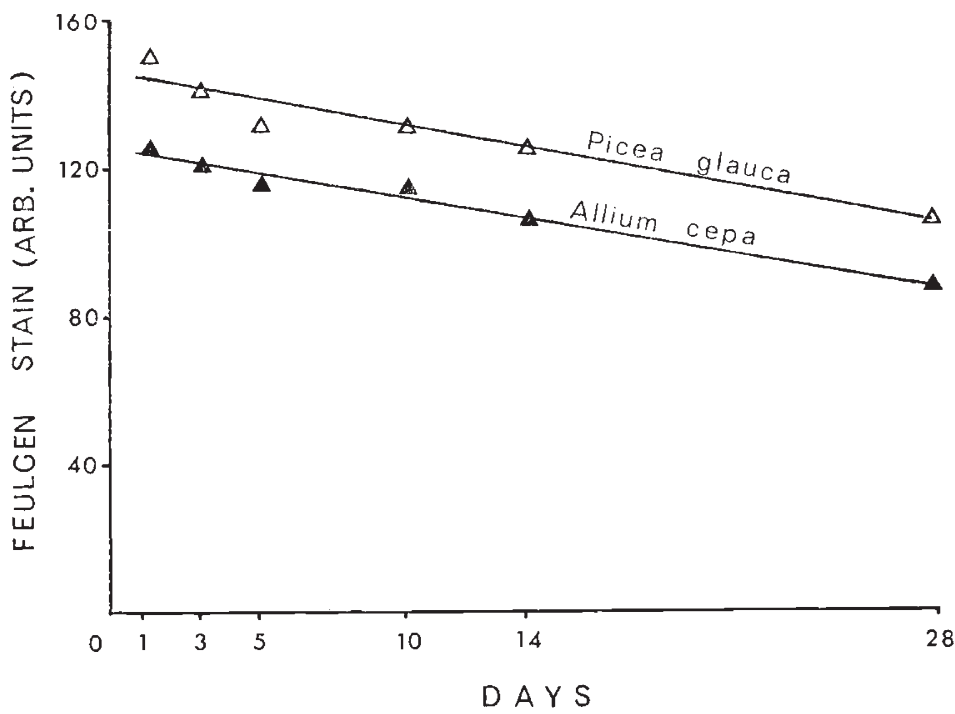

FIG. 3.-The relationship between intensity of Feulgen stain and the time interval between staining and scoring.

The unweighted values. Table 3 shows that the means of the unweighted DNA values vary substantially, by more than 30 per cent between experiments, which confirms a substantial "error" in DNA estimates between different batches (experiments) with respect to the intensity of staining with Feulgen. Glearly conclusions based on these unweighted values would be unwarranted and the use of the standard species, therefore, is of extreme importance in carrying out a DNA survey of this kind.

The weighting procedure. Weighting was achieved by multiplying the Picea glauca values in each replicate in each experiment by the ratio,

$$
k_{i}=\frac{\text { Mean of } A . \text { cepa values in all experiments }}{\text { Value of } A \text {. cepa in each replicate }}
$$

This weighting "corrects" for differences due to technical variation in staining procedures between experiments. Equally important, the weighting on the basis of replicate corrects for any fading of the dye between staining and scoring within experiments (the replicates in each experiment are numbered in the order of scoring). That fading is indeed a source of variation in estimating the nuclear DNA is also apparent from the graph in fig. 3. It shows the decrease in DNA estimates with increasing interval following the staining. A regression analysis showed that the fading effect was highly significant; also, that the rate of fading is the same for both White Spruce and the Allium control which means that weighting relative to the control is justified and, moreover, straightforward.

36/1-I 
The weighted values. The weighted values are presented in table 4 . An analysis of the data is presented in table 5. The conclusions from this analysis are as follows:

(i) There are no significant differences between replicates within experiments.

(ii) There are no significant differences between experiments.

(iii) The interaction between replicates and experiments is not significant.

(iv) There are also no significant differences between provenances overall or between Eastern and Western provenances within experiments.

TABLE 4

Weighted DNA amounts in 2C nuclei of Picea glauca from 26 provenances

\begin{tabular}{|c|c|c|c|c|c|c|c|}
\hline & & & & Repl & cate & & \\
\hline & Expt. & Code & $\mathrm{R} 1^{*}$ & R2 & R3 & R4 & Mean \\
\hline & (1) & 57 & $159 \cdot 13$ & $158 \cdot 92$ & 153.99 & $156 \cdot 58$ & $157 \cdot 15$ \\
\hline & 3-year-old & 81 & $158 \cdot 82$ & $159 \cdot 29$ & $156 \cdot 69$ & $157 \cdot 03$ & 157.96 \\
\hline & plants & 82 & 158.49 & $157 \cdot 83$ & $159 \cdot 38$ & $158 \cdot 81$ & $158 \cdot 63$ \\
\hline & & 63 & 155.58 & $156 \cdot 07$ & $156 \cdot 74$ & $160 \cdot 64$ & $157 \cdot 26$ \\
\hline & & 65 & 152.94 & $159 \cdot 20$ & $160 \cdot 83$ & $161 \cdot 45$ & $158 \cdot 61$ \\
\hline $\begin{array}{l}\text { Western } \\
\text { provenances }\end{array}$ & (2) & 71442 & 159.66 & 156.65 & 156.59 & 158.09 & 157.75 \\
\hline & Seeds & 9313 & $\begin{array}{l}159 \cdot 00 \\
158 \cdot 54\end{array}$ & $\begin{array}{l}150 \cdot 03 \\
157 \cdot 50\end{array}$ & $\begin{array}{l}130 \cdot 39 \\
157 \cdot 02\end{array}$ & $159 \cdot 46$ & $158 \cdot 13$ \\
\hline & & $104 \mathrm{~A} 6$ & $158 \cdot 21$ & $161 \cdot 77$ & $157 \cdot 13$ & $157 \cdot 02$ & $158 \cdot 53$ \\
\hline & & $94 \mathrm{~J} 15$ & $157 \cdot 10$ & $156 \cdot 56$ & 160.83 & $156 \cdot 04$ & $157 \cdot 63$ \\
\hline & & 72374 & $158 \cdot 56$ & $161 \cdot 47$ & $159 \cdot 65$ & $157 \cdot 75$ & $159 \cdot 36$ \\
\hline & & GK 06 & $162 \cdot 41$ & $158 \cdot 85$ & $158 \cdot 52$ & $151 \cdot 81$ & $157 \cdot 90$ \\
\hline & (3) & 391 & $157 \cdot 81$ & $161 \cdot 78$ & $160 \cdot 95$ & $152 \cdot 71$ & $158 \cdot 31$ \\
\hline & 3-year-old & 467 & $157 \cdot 54$ & $154 \cdot 35$ & $158 \cdot 39$ & $166 \cdot 98$ & $159 \cdot 32$ \\
\hline & & 403 & $157 \cdot 78$ & $157 \cdot 80$ & $156 \cdot 77$ & $155 \cdot 69$ & $157 \cdot 01$ \\
\hline & & 395 & $157 \cdot 02$ & $152 \cdot 34$ & $162 \cdot 69$ & $164 \cdot 18$ & 159.06 \\
\hline & (4) & 70112 & $160 \cdot 20$ & $156 \cdot 98$ & $158 \cdot 49$ & $156 \cdot 21$ & 157.97 \\
\hline & Seeds & 70079 & $161 \cdot 15$ & $161 \cdot 62$ & $156 \cdot 74$ & $156 \cdot 71$ & $159 \cdot 05$ \\
\hline & & 72114 & $161 \cdot 63$ & $158 \cdot 19$ & $156 \cdot 43$ & $155 \cdot 33$ & $157 \cdot 89$ \\
\hline Lastern \{ & & 70118 & $160 \cdot 61$ & $158 \cdot 26$ & $155 \cdot 60$ & $159 \cdot 62$ & $158 \cdot 52$ \\
\hline & & 70075 & $160 \cdot 66$ & $156 \cdot 18$ & $157 \cdot 75$ & $154 \cdot 62$ & $157 \cdot 30$ \\
\hline & (5) & 71045 & $155 \cdot 03$ & $158 \cdot 78$ & $157 \cdot 52$ & $158 \cdot 07$ & $157 \cdot 35$ \\
\hline & Seeds & 70076 & $158 \cdot 60$ & 153.65 & $162 \cdot 15$ & $163 \cdot 17$ & $159 \cdot 39$ \\
\hline & & 72127 & $158 \cdot 27$ & $156 \cdot 32$ & 155.95 & $155 \cdot 77$ & $165 \cdot 58$ \\
\hline & & 70114 & $160 \cdot 05$ & $157 \cdot 23$ & $158 \cdot 11$ & $158 \cdot 74$ & $158 \cdot 33$ \\
\hline & & 70113 & $155 \cdot 11$ & 157.79 & 155.89 & $156 \cdot 42$ & $156 \cdot 30$ \\
\hline & & 70074 & $157 \cdot 14$ & $156 \cdot 44$ & $158 \cdot 36$ & $158 \cdot 38$ & 157.58 \\
\hline
\end{tabular}

* Values within each replicate are derived from the mean of $152 C$ nuclei in the root-tip of one plant or seedling. R1 was the first scored, R4 the last in each experiment.

These results are very different from those reported by Miksche (1968). In particular, the data above gave no indication of nuclear DNA variation between plants from different provenances. Indeed it will be seen from table 4 that the DNA values for diploid $2 C$ nuclei are remarkably consistent between plants both within and between provenances. 
TABLE 5

Analysis of variance of mean DNA amounts from the White Spruce provenances (weighted means)

\begin{tabular}{|c|c|c|c|c|}
\hline Item & S.S. & d.f. & M.S. & V.R. \\
\hline $\begin{array}{l}\text { Between West and East } \\
\text { provenances }\end{array}$ & $0 \cdot 1268$ & 1 & $0 \cdot 1268$ & 0.0175 \\
\hline $\begin{array}{l}\text { Between experiments within } \\
\text { areas }\end{array}$ & $7 \cdot 7168$ & 3 & $2 \cdot 5723$ & $0 \cdot 3550$ \\
\hline $\begin{array}{l}\text { Between provenances within } \\
\text { experiments }\end{array}$ & $63 \cdot 6529$ & 21 & 3.0311 & 0.4184 \\
\hline Between replicates & $5 \cdot 2620$ & 3 & 1.7540 & 0.2421 \\
\hline Replicates $\times$ experiments & 124.567 & 12 & $10 \cdot 3806$ & 1.4328 \\
\hline Error & $456 \cdot 4360$ & 63 & $7 \cdot 2450$ & - \\
\hline Total & $657 \cdot 7615$ & 103 & & \\
\hline
\end{tabular}

Regression analysis. According to Miksche (loc. cit.) the nuclear DNA amount varies in White Spruce in relation to latitude, being higher in northern than in southern provenances. A possibility, therefore, was that a regression analysis of variance of DNA means on to latitude could be a more sensitive test for nuclear DNA variation between the populations. A joint regression analysis, combining the data from all five experiments, showed no evidence of DNA change in relation to latitude $(P=>0 \cdot 20)$.

The present results, therefore, give no support to claims of a large scale intraspecific nuclear DNA variation in White Spruce. Before reaching a firm conclusion, however, two other kinds of measurements may be used as evidence. Nuclear DNA amounts are positively correlated with nuclear size (expressed either as volume or area; Baetcke et al., 1967; Sparrow et al., 1972) and with chromosome volume (Rees, 1972). If, therefore, the DNA amounts do indeed vary between provenances we would expect to find differences between provenances in respect of nuclear area and chromosome volume. The two characters are dealt with below.

\section{(c) Variation in nuclear area}

The average areas of $\mathrm{Gl}$ nuclei in roots of germinating seeds from provenances at each of six latitudes from the Western and Eastern ranges, along with the areas of Allium cepa controls are shown in table 6 . It will be observed that the $A$. cepa values measured alongside $P$. glauca from Eastern and Western provenances are virtually identical. This is confirmed by an analysis of variance which shows a probability level of between 10 and 20 per cent. No weighting was required, therefore, for analysing the White Spruce data. An analysis of variance of the nuclear areas showed:

(i) There are no differences between replicates within experiments $(\mathrm{P}=>0 \cdot 20)$.

(ii) There are no differences in the mean nuclear areas between provenances overall $(\mathrm{P}=>0 \cdot 20)$ or between provenances within Eastern and Western areas $(\mathrm{P}=0 \cdot 10)$.

(iii) The interaction item is also not significant $(\mathrm{P}=0 \cdot 10)$.

From these results there is no indication whatsoever of variation in nuclear size among plants from different provenances. Since nuclear size is 
strongly correlated with nuclear DNA content the results fully support the conclusion from DNA estimates above that the amount of DNA per nucleus is constant both between and within provenances.

TABLE 6

Mean area of $2 \mathrm{C}$ nuclei (based on 15 cells in each replicate, $R$ ) in root-tips of germinating seeds of White Spruce and Allium cepa

$\begin{array}{cl}\text { Provenance } \\ \text { Western } & 71442 \\ & 9313 \\ & 104 \mathrm{~A} 6 \\ & 94 \mathrm{~J} 15 \\ & 72374 \\ & \text { GK } 06 \\ \text { Eastern } & 72127 \\ & 70114 \\ & 70113 \\ & 70076 \\ & 71045 \\ & 70074\end{array}$

Allium cepa (control)

With Western provenances With Eastern provenances

\begin{tabular}{|c|c|c|c|c|}
\hline \multicolumn{4}{|c|}{ Area (arbitrary units) } & \multirow[b]{2}{*}{ Mean } \\
\hline R1 & $\mathrm{R} 2$ & R3 & R4 & \\
\hline $36 \cdot 05$ & 34.97 & $32 \cdot 77$ & $34 \cdot 17$ & $34 \cdot 49$ \\
\hline $33 \cdot 70$ & $36 \cdot 71$ & $34 \cdot 21$ & $33 \cdot 88$ & $34 \cdot 63$ \\
\hline 36.99 & $32 \cdot 13$ & $33 \cdot 17$ & $35 \cdot 29$ & $34 \cdot 39$ \\
\hline $36 \cdot 02$ & $37 \cdot 81$ & $35 \cdot 44$ & $32 \cdot 20$ & $35 \cdot 37$ \\
\hline $37 \cdot 85$ & $38 \cdot 15$ & $37 \cdot 10$ & $35 \cdot 89$ & $37 \cdot 25$ \\
\hline $34 \cdot 37$ & $36 \cdot 38$ & $33 \cdot 24$ & $34 \cdot 83$ & $34 \cdot 71$ \\
\hline $35 \cdot 49$ & $35 \cdot 64$ & $38 \cdot 33$ & $35 \cdot 86$ & $36 \cdot 33$ \\
\hline $35 \cdot 32$ & $35 \cdot 76$ & $34 \cdot 02$ & 34.95 & $35 \cdot 01$ \\
\hline $34 \cdot 40$ & $34 \cdot 61$ & $37 \cdot 84$ & $34 \cdot 29$ & $35 \cdot 28$ \\
\hline $32 \cdot 67$ & 35.92 & $35 \cdot 63$ & 33.67 & $34 \cdot 47$ \\
\hline $33 \cdot 79$ & $34 \cdot 10$ & $33 \cdot 48$ & 35.95 & $34 \cdot 23$ \\
\hline $37 \cdot 69$ & $35 \cdot 96$ & $37 \cdot 02$ & $34 \cdot 52$ & $36 \cdot 30$ \\
\hline \multicolumn{4}{|c|}{ Area (arbitrary units) } & \\
\hline Rl & $\mathrm{R} 2$ & R3 & $\mathrm{R} 4$ & Mean \\
\hline $26 \cdot 36$ & $25 \cdot 39$ & $27 \cdot 46$ & $25 \cdot 48$ & $26 \cdot 17$ \\
\hline $24 \cdot 06$ & $25 \cdot 36$ & $26 \cdot 29$ & $25 \cdot 00$ & $25 \cdot 18$ \\
\hline
\end{tabular}

\section{(d) Variation in chromosome volume}

Chromosome volumes were calculated from the lengths and widths of the chromosomes at $c$-metaphases in root-tips from $\mathrm{OB}$ seeds from three provenances and their values are presented in table 7 . The mean for each replicate was estimated from at least two $c$-metaphases. An analysis of variance of the data showed insignificant differences between provenances $(\mathrm{P}=>0 \cdot 20)$.

\section{TABLE 7}

Chromosome volumes in $O B$ seedlings from three provenances of White Spruce

\begin{tabular}{cccccc} 
& \multicolumn{4}{c}{ Chromosome volume (cu. units) } & \\
\cline { 2 - 5 } Provenance & R1 & R2 & R3 & R4 & Mean \\
$481-2$ & $336 \cdot 99$ & $308 \cdot 86$ & $283 \cdot 80$ & $309 \cdot 35$ & $309 \cdot 75$ \\
$477-2$ & $388 \cdot 08$ & $315 \cdot 23$ & $267 \cdot 83$ & $253 \cdot 56$ & $306 \cdot 18$ \\
395 & $325 \cdot 82$ & $329 \cdot 00$ & $357 \cdot 87$ & 303.93 & $329 \cdot 15$
\end{tabular}

The comparisons between chromosome volumes together with those of the nuclear areas provide confirmation for the conclusion that there is no nuclear DNA variation between plants of White Spruce provenances and, on the basis of these results, no case for separating White Spruce provenances, on grounds of quantitative DNA variation, into Eastern and Western sections as proposed by Miksche (1968). Whatever genetic differences apply to White Spruce from different regions would, on our evidence, be quite independent of quantitative changes in nuclear DNA content. 


\section{(ii) A comparison of DNA values in White and Engelmann spruce}

The distributions of "pure" White Spruce and Engelmann Spruce overlap at altitudes representing the upper limits of White Spruce and the lower limits of Engelmann Spruce. Hybrids also occur at these regions of sympatry between the two parents (Roche, 1969). It would be of interest to test whether White and Engelmann Spruce differ in their nuclear DNA content and, if they do, whether their hybrids would have a DNA content intermediate between the two parents. If this were the case quantitative DNA variation within either species could result from introgression. For this investigation, provenances in which seeds were collected at different heights came from within the area of overlap. The six selected provenances are listed in table 8 and arranged according to elevation.

TABle 8

Mean DNA values of $2 \mathrm{C}$ nuclei of White Spruce (WS) and Engelmann Spruce (ES)

\begin{tabular}{|c|c|c|c|c|c|c|}
\hline \multirow[b]{2}{*}{ Species } & \multirow[b]{2}{*}{ Code } & \multicolumn{4}{|c|}{ DNA amounts (arb. units) } & \multirow[b]{2}{*}{ Mean } \\
\hline & & $\begin{array}{l}\text { Alt. } \\
\text { (ft.) }\end{array}$ & R1 & R2 & R3 & \\
\hline WS & DA 66-78 & 800 & $163 \cdot 16$ & $160 \cdot 46$ & $165 \cdot 32$ & $162 \cdot 98$ \\
\hline WS & 71442 & 1400 & $164 \cdot 99$ & $158 \cdot 82$ & $165 \cdot 58$ & $163 \cdot 13$ \\
\hline $\mathrm{ES}$ & N 27 & 4000 & $169 \cdot 15$ & $161 \cdot 94$ & $163 \cdot 53$ & $164 \cdot 87$ \\
\hline WS & 82 & 4300 & $166 \cdot 60$ & $163 \cdot 14$ & $161 \cdot 51$ & $163 \cdot 75$ \\
\hline $\mathrm{ES}$ & N 110 & 5300 & $163 \cdot 19$ & $161 \cdot 47$ & $162 \cdot 71$ & $162 \cdot 46$ \\
\hline $\mathrm{ES}$ & N 86 & 5500 & $162 \cdot 30$ & $163 \cdot 00$ & $160 \cdot 93$ & $162 \cdot 08$ \\
\hline \multicolumn{3}{|c|}{ Allium cepa (control) } & $136 \cdot 38$ & $134 \cdot 56$ & $135 \cdot 56$ & $135 \cdot 50$ \\
\hline
\end{tabular}

Germinating root-tips were treated in a manner suitable for microdensitometry as described previously. Again Allium cepa is used as a control in each replicate. The DNA readings in each replicate in the provenances are set out in table 8 . An analysis showed that there are no significant differences between replicates $(P=0 \cdot 05-0 \cdot 10)$ or provenances $(P=>0 \cdot 20)$ indicating that Engelmann Spruce have a DNA value very similar to that of White Spruce. It follows, therefore, from this result that their hybrids would have DNA values which are no different from those of the parents. Hybridity between the two species could not, therefore, be a source of nuclear DNA variation (by introgression) among provenances either of White Spruce or Engelmann Spruce.

\section{(iii) $D \mathcal{N} A$ amounts in different provenances of Pinus contorta}

It was thought worthwhile to extend the nuclear DNA survey, such as was conducted for White Spruce, to another Gymnosperm species to find out if an intraspecific variation in nuclear DNA amount of the magnitude reported in table 1 (see Introduction) could be discerned. The species chosen for this purpose is Pinus contorta.

\section{(a) Nuclear DNA variation}

For measurements of the DNA content of nuclei, root-tips of germinating seeds were treated according to the schedule described for microdensitometry in Methods. Since B chromosomes were not found in any of the nine 
provenances (see fig. 2b), it was, therefore, unnecessary to screen the squash preparations before readings were taken of the $2 C$ nuclei. Allium cepa was again used as a control.

Each replicate value per provenance is the mean of $152 C$ nuclei chosen at random from one root-tip squash preparation. Altogether three replicates were scored for each provenance. The results are presented in table 9 .

TABLe 9

Mean DNA amounts in $2 \mathrm{C}$ nuclei of Pinus contorta

A. Unweighted values

\begin{tabular}{|c|c|c|c|c|}
\hline \multirow{2}{*}{$\begin{array}{l}\text { Provenances } \\
\text { code }\end{array}$} & \multicolumn{3}{|c|}{ DNA amounts (arb. units) } & \multirow[b]{2}{*}{ Mean } \\
\hline & R1 & $\mathrm{R} 2$ & R3 & \\
\hline $65(7114) 13$ & $137 \cdot 39$ & $124 \cdot 28$ & $103 \cdot 37$ & $121 \cdot 68$ \\
\hline $72(7114) 1$ & $138 \cdot 43$ & $125 \cdot 62$ & $105 \cdot 28$ & $123 \cdot 11$ \\
\hline $65(7113) 1$ & $135 \cdot 31$ & $122 \cdot 38$ & $105 \cdot 92$ & $121 \cdot 20$ \\
\hline $65(7113) 3$ & $136 \cdot 68$ & $125 \cdot 42$ & $104 \cdot 66$ & $122 \cdot 25$ \\
\hline $65(7118) 1$ & $135 \cdot 51$ & $124 \cdot 49$ & $103 \cdot 44$ & $121 \cdot 15$ \\
\hline $65(795)$ & $138 \cdot 78$ & $128 \cdot 27$ & $104 \cdot 51$ & $123 \cdot 83$ \\
\hline $63(7957)$ & $136 \cdot 33$ & $124 \cdot 52$ & $105 \cdot 36$ & $122 \cdot 07$ \\
\hline $72(4625) 1$ & $137 \cdot 99$ & $126 \cdot 64$ & $103 \cdot 58$ & $122 \cdot 74$ \\
\hline $72(4265) 2$ & 134.93 & $127 \cdot 58$ & $105 \cdot 28$ & $122 \cdot 60$ \\
\hline Allium cepa (control) & $114 \cdot 28$ & $103 \cdot 73$ & $86 \cdot 70$ & $101 \cdot 57$ \\
\hline
\end{tabular}

B. Weighted values

\begin{tabular}{|c|c|c|c|c|}
\hline \multirow{2}{*}{$\begin{array}{l}\text { Provenances } \\
\text { code }\end{array}$} & \multicolumn{3}{|c|}{ DNA amounts (arb. units) } & \multirow[b]{2}{*}{ Mean } \\
\hline & R1 & R2 & R3 & \\
\hline $65(7114) 13$ & $122 \cdot 10$ & $121 \cdot 68$ & $121 \cdot 10$ & $121 \cdot 63$ \\
\hline $72(7114) 1$ & $123 \cdot 02$ & $122 \cdot 99$ & $123 \cdot 33$ & $123 \cdot 11$ \\
\hline $65(7113) 1$ & $120 \cdot 25$ & $119 \cdot 82$ & $124 \cdot 08$ & $121 \cdot 38$ \\
\hline $65(7113) 3$ & $121 \cdot 47$ & $122 \cdot 80$ & $122 \cdot 61$ & $122 \cdot 29$ \\
\hline $65(7118) 1$ & $120 \cdot 43$ & $121 \cdot 89$ & $121 \cdot 18$ & $121 \cdot 17$ \\
\hline $65(795)$ & $123 \cdot 33$ & $125 \cdot 59$ & $122 \cdot 43$ & $123 \cdot 78$ \\
\hline $63(7957)$ & $121 \cdot 16$ & $121 \cdot 92$ & $123 \cdot 43$ & $122 \cdot 17$ \\
\hline $72(4625) 1$ & $122 \cdot 63$ & 123.99 & $121 \cdot 34$ & 122.65 \\
\hline $72(4265) 2$ & $119 \cdot 91$ & $124 \cdot 91$ & 123.33 & $122 \cdot 72$ \\
\hline
\end{tabular}

As in the case of the DNA experiments in White Spruce, it can be clearly seen (table 9a) that there is considerable fading of stain in the Pinus contorta values from the first to the last replicate. This is also reflected in the replicates of the control, Allium cepa. Therefore, before the data were analysed they were weighted in relation to the control, as described for White Spruce.

The analysis of variance of the weighted data showed no significant differences between replicates or provenances. In fact, it can be observed (see table $9 \mathrm{~b}$ ) that the mean nuclear DNA amounts are remarkably consistent between provenances in this pine species as was the case in the spruce species. Thus there is no indication from this survey of an intraspecific nuclear DNA variation in Pinus contorta. The nuclear DNA amounts, as in White Spruce, are constant among provenances.

(b) Nuclear area variation

The mean nuclear area of Gl nuclei for each replicate in each replicate in each provenance are presented in table 10. The analysis of variance of 
the nuclear area data again showed no significant differences between provenances $(P>0 \cdot 20)$ or between replicates $(P=0 \cdot 05-0 \cdot 10)$.

Taken together, the findings reinforce the conclusion of constancy in nuclear genetic material among provenances of Pinus contorta.

TABLE 10

Mean area of $\mathrm{G} 1$ nuclei of Pinus contorta

\begin{tabular}{lcccc}
$\begin{array}{l}\text { Provenances } \\
\text { code }\end{array}$ & \multicolumn{3}{c}{ DNA amounts (arb. units) } & \\
$65(7114) 13$ & $\overbrace{\mathrm{R} 1}$ & $\mathrm{R} 2$ & $\mathrm{R} 3$ & Mean \\
$72(7114) 1$ & $27 \cdot 52$ & $29 \cdot 94$ & $26 \cdot 77$ & $28 \cdot 08$ \\
$65(7113) 1$ & $27 \cdot 78$ & $26 \cdot 61$ & $26 \cdot 75$ & $27 \cdot 05$ \\
$65(7113) 3$ & $29 \cdot 16$ & $28 \cdot 80$ & $25 \cdot 64$ & $27 \cdot 87$ \\
$65(7118) 1$ & $26 \cdot 81$ & $27 \cdot 00$ & $27 \cdot 18$ & $27 \cdot 00$ \\
$65(795)$ & $29 \cdot 77$ & $27 \cdot 33$ & $24 \cdot 97$ & $27 \cdot 36$ \\
$63(7957)$ & $27 \cdot 54$ & $28 \cdot 98$ & $28 \cdot 02$ & $28 \cdot 18$ \\
$72(4265) 1$ & $27 \cdot 80$ & $28 \cdot 96$ & $28 \cdot 74$ & $28 \cdot 50$ \\
$72(4265) 2$ & $27 \cdot 83$ & $29 \cdot 95$ & $28 \cdot 47$ & $28 \cdot 75$ \\
\multicolumn{1}{|c|}{ Allium cepa (control) } & $22 \cdot 24$ & $28 \cdot 28$ & $27 \cdot 04$ & $27 \cdot 85$ \\
& & $21 \cdot 29$ & $21 \cdot 54$ & $21 \cdot 72$
\end{tabular}

\section{Disgussion}

Miksche (1968) has reported large scale differences in nuclear DNA amount between plants from different provenances of Picea glauca. He claimed that such differences were the consequences of amplification of chromosomal DNA segments within the normal diploid complement and, further, that they were a reflection of adaptation to different environments. In complete contrast to the results of Miksche (1968) and of others our own results showed a remarkable constancy in the amount of nuclear DNA in diploid complements in root meristems of Picea glauca plants from different provenances and, as well, from within provenances. The provenances investigated were from locations representing a wide range of latitudes and longitudes and, also, of altitudes within North America. There was no suggestion of an adaptive change in the quantity of nuclear DNA due to the amplification of chromosome segments. The investigation did, however, establish a nuclear DNA variation within and between provenances due to $\mathrm{B}$ chromosomes. We have evidence to show that the DNA variation due to $B$ 's is, indeed, of an adaptive nature, as will be described in a later publication.

As in Picea glauca the DNA values among plants of Pinus contorta and of Picea engelmanni showed the same degree of uniformity. The weight of evidence argues strongly against the notion that intraspecific DNA variation is a common phenomenon in Gymnosperm species (see Dhir and Miksche, 1974). Indeed it raises the question as to whether this type of DNA variation exists at all in members of this group of plants. It will be recalled that nuclear DNA differences of the order of 60 per cent had been reported between provenances of White Spruce and even bigger differences between provenances of Sitka Spruce (Picea sitchensis). To account for the intraspecific DNA variation reported one possibility is, of course, that it is attributable to B chromosome variation. In maize, for example, B chromosomes may increase the nuclear DNA amont by 155 per cent (Rees, 1974). 
As will be shown in a separate paper, B's could indeed account for some of the DNA variation in White Spruce but nowhere near the 60 per cent reported. The alternative explanation for the intraspecific DNA variation reported is that it reflects errors in estimation. The many contradictory reports in the literature concerning nuclear DNA variation in the Gymnosperms tend to confirm that this is so. Firstly, the magnitude of the variation reported seems to depend very largely upon the method used by the investigator to estimate the DNA amount. In Picea sitchensis Miksche (1971), using densitometric techniques, found 36 per cent variation in DNA but this was increased to 72 per cent by cytophotometrical estimations and finally to 92 per cent by "biochemical " means. It should be stressed that the seeds used were derived from the same provenances. Secondly, when the variation in DNA amounts within different species was correlated with latitude, there seemed to be no agreement between different groups of investigators irrespective of whether they use the same or different methods of estimation. For example, in Picea glauca the nuclear volume, as an index of DNA content, was significantly correlated with latitude according to Mergen and Thielges (1967) but Miksche (1968) found no significant correlation. In Pinus banksiana, the nuclear volume showed significant correlation with latitude (Mergen and Thielges, 1967) yet the nuclear DNA amount measured directly by cytophotometry is not significantly correlated with latitude (Miksche, 1968).

We have pointed out that the more conventional photometric techniques, such as those followed by Miksche and his co-workers, proved unsuitable and unreliable for these Gymnosperm species. Another source of error is the fluctuation in DNA estimates within and between experimental samples due to uncontrollable factors of environment and procedure. The use of the standard, as we have emphasised, to monitor and correct for these "errors" is of paramount importance. Having taken these precautions we find no evidence for intraspecific DNA variation among diploids of Picea glauca or of the other species investigated. The results conform with those from numerous other surveys in testifying, in the absence of numerical chromosome changes, to a remarkable, and indeed surprising, constancy in the nuclear DNA amount among the chromosome complements of individuals within the same species.

Acknowledgments.-S. B. T. acknowledges with gratitude the receipt of a scholarship from the Commonwealth Scholarship Commission in the United Kingdom.

\section{REFERENCES}

BAETCKe, K. P., SPARRow, A. H., NAUMAN, C. H., AND SCHWEMmer, s. s. 1967. The relationship of DNA content to nuclear and chromosome volumes and to radiosensitivity $\left(\mathrm{LD}_{50}\right)$. Proc. Natn. Acad. Sci. U.S.A., 58, 533-540.

BOIVIN, A., VENDRELY, R., AND VENDRELY, C. 1948. L'Acide désoxyribonucléique du noyau cellulaire, dépositaire des caractéres héréditaires; arguments d'ordre analytique. C.R. Acad. Sci. Paris, 226, 1061-1063.

DECosse, J. J., AND AIEllo, N. 1966. Feulgen hydrolysis: effect of acid and temperature. 7. Histochem. Cytochem., 14, 601-604.

DEITCH, A. D., WAGNER, D., AND RICHART, R. M. 1968. Conditions influencing the intensity of the Feulgen reaction. F. Histochem. Cystochem., 16, 371-379.

DHIR, N. K., AND MIKSCHE, J. P. 1974. Intraspecific variation of nuclear DNA content in Pinus resinosa Ait. Can. F. Genet. Cytol., 16, 77-83. 
EDWARDS, G. A., ENDRIzzI, J. E., AND STEIN, R. 1974. Genome DNA content and chromosome organisation in Gossypium. Chromosoma, 47, 309-326.

EL-LAKANY, M. H., AND SZIKLAI, O. 1971. Intraspecific variation in nuclear characteristics of Douglas-Fir. Advan. Front. Plant. Sci., 28, 363-378.

FLAVELL, R. B., AND SMITH, D. B. 1974. Variation in nucleolar organiser rRNA gene multiplicity in wheat and rye. Chromosoma, 47, 327-334.

Fox, D. P. 1969a. Some characteristics of the cold hydrolysis technique for staining plant tissues by the Feulgen reaction. F. Histochem. Cytochem., 17, 266-272.

Fox, D. P. 1969b. The relationship between DNA value and chromosome volume in the Coleopteran genus Dermestes. Chromosoma, 27, 130-144.

MERGEN, F., AND THIELGES, B. A. 1967. Intraspecific variation in nuclear volume in four conifers. Evolution, 21, 720-724.

MIKSCHE, J. P. 1968. Quantitative study of intraspecific variation of DNA per cell in Picea glauca and Pinus banksiana. Can. 7. Genet. Cytol., 10, 590-600.

MIKSCHE, J. P. 1971. Intraspecific variation of DNA per cell between Picea sitchensis (Bong.) Carr. provenances. Chromosoma, 32, 343-352.

MIRSKY, A. E., AND RIs, H. 1949. Variable and constant components of chromosomes. Nature, 163, 666-667.

REES, H. 1972. DNA in higher plants. Brookhaven Symp. Biol., 23, 394-418.

ReEs, H. 1974. B Chromosomes. Sci. Prog., 61, 535-554.

RITOSSA, F. M., AND SPIEgElmaN, s. 1965. Localization of DNA complementary to ribosomal RNA in the nucleolus organizer region of Drosophila melanogaster. Proc. Natn. Acad. Sci. U.S.A., 53, 737-745.

Roche, L. 1969. A genecological study of the genus Picea in British Columbia. New Phytol., $68,505-554$.

ROthfels, K., SEXSMith, E., heimburger, M., AND krause, M. o. 1966. Chromosome size and DNA content of species of Anemone and related genera (Ranunculaceae). Chromosoma, 20, 54-74.

SPARROW, A. H., PRICE, H. J., AND UNDERbrink, A. G. 1972. A survey of DNA content per cell and per chromosome of prokaryotic and eukaryotic organisms: some evolutionary considerations. Brookhaven Symp. Biol., 23, 451-494.

swIFT, H. 1950a. The desoxyribose nucleic acid content of animal nuclei. Physiol. Zoo., 23, 169-198.

swifT, H. 1950b. The constancy of desoxyribose nucleic acid in plant nuclei. Proc. Natn. Acad. Sci. U.S.A., 36, 643-654. 